\title{
TINJAUAN YURIDIS PENERAPAN HUKUM TERHADAP PELAKU TINDAK PIDANA PEMERKOSAAN TERHADAP ANAK KANDUNG
}

\author{
Muhammad Idran
}

Dosen Fakultas Hukum STIH Muhammadiyah Kotabumi, Lampung

\begin{abstract}
Abstrak
Tujuan penelitian ini adalah untuk mengetahui pertimbangan hukum bagi hakim atas tindak pidana perkosaan yang dilakukan oleh pelaku terhadap anak kandungnya, dan juga untuk mengetahui putusan apa yang akan dijatuhkan oleh hakim kepada pelaku tindak pidana pemerkosaan terhadap anak kandung. Metode penelitian yang digunakan adalah dengan cara pendekatan normative dan emperis. Hasil penelitian menunjukkan bahwa perbuatan pidana yang dilakukan terdakwa adalah tindak pidana perkosaan terhadap anak kandung sebagaimana dakwaan jaksa penuntut umum melanggar ketentuan Pasal 81 Ayat 1 UndangUndang Nomor 23 tahun 2002 Tentang Perlindungan anak Jo Pasal 64 Ayat (1) KUHP, sedangkan dalam pertimbangan hakim dalam putusannya menyatakan, hal yang memberatkan adalah perbuatan terdakwa telah menghancurkan masa depan saksi korban, sedangkan tidak ada alasan yang meringankan bagi terdakwa. Disarankan agar Hakim dalam menjatuhkan pidana, apabila atas diri terdakwa tidak ada hal yang meringankan, maka Hakim harus menjatuhkan hukuman maksimal, yaitu selama 15 tahun bukan selama 12 tahun, dan juga harus menjatuhkan hukuman denda paling sedikit Rp 60.000.000,00 (enam puluh juta rupiah) sesuai dengan Pasal 81 Ayat (1) Undang-Undang Nomor 23 Tahun 2002.

Kata kunci : tindak pidana, pemerkosaan anak kandung, dan sanksi pidana
\end{abstract}

\section{PENDAHULUAN}

Permasalahan yang akan dibahas dalam tulisan ini adalah membahas tentang Hak Asasi manusia (HAM) pada segala aspek kehidupan, khususnya terkait dengan perlindungan hukum terhadap anak. Masalahnya perlindungan anak baru menjadi perhatian masyarakat Indonesia pada kurun waktu tahun 1990an, setelah secara intensif berbagai bentuk kekerasan terhadap anak yang dilakukan orang tua. Masalah anak di Indonesia diangkat kepermukaan oleh berbagai kalangan. Fenomena serupa muncul pula diberbagai kawasan Asia lainnya, seperti di Thailand, Vietnam dan Philipina, sehingga dengan cepat isu ini menjadi regional bahkan global yang memberikan inspirasi kepada masyarakat dunia tentang pentingnya membahas permasalahan ini.

Masalah ekonomi dan sosial yang melanda Indonesia berdampak pada peningkatan skala dan kompleksitas yang di hadapi anak Indonesia yang ditandai dengan makin banyaknya anak yang mengalami perlakuan salah, eksploitasi, tindak kekerasan, anak yang diperkosa, penelantaran, disamping anak-anak yang tinggal di 
daerah rawan konflik, rawan bencana serta anak yang berhadapan dengan hukum dan lain-lainnya.

Berbagai informasi yang valid atau akurat menyangkut pemerkosaan anak untuk tujuan kepuasan syahwat. Begitu pula terdapat berbagai macam indikator mengenai pemerkosaan anak yang umumnya rata-rata berusia 16 tahun, dimana bukan hanya anak-anak perempuan yang menjadi korban tetapi juga anak laki-laki yang menjadi korban perlakuan seksual tersebut.

Masih berkaitan dengan persoalan ini adalah bahwa anakanak yang obyek seksual menjadi seperti muara atau sebab dari segala persoalan yang ada. Pekerjaan dan anak-anak jalanan dengan amat mudah sekali terjebak oleh orang tuanya . Anak-anak di bawah umur berada dalam posisi yang sangat tidak menguntungkan, bahkan boleh dikatakan mereka berada pada garis bahaya yang akan menggangu tumbuh kembang mereka sebagai seorang anak.

Kasus yang pernah terjadi dan terungkap di Rawa jitu Selatan Kabupaten Tulang Bawang adalah kasus sorang ayah yang bernama Yantori Bin Nengkuasa,(selanjutnya disebut Pelaku), telah memperkosa anak kandungnya sendiri yang bernama Nopitasari (yang selanjutnya disebut Korban).

Beberapa polemik yang muncul selama persidangan, seperti klaim tidak terjadi kasus pelanggaran Undang-Undang Perlindungan Anak (UUPA) dalam kasus ini dengan klaim tidak terjadi kekerasan dan paksaan terhadap korban, menunjukkan betapa sering dikacaukan pengertiannya. Ada tidaknya unsur kekerasan fisik masih sering dijadikan kriteria untuk mengategorikan tindak pelecehan seksual terhadap anak kandung sebagai bentuk kejahatan atau tidak. Pelecehan seksual terhadap anak sendiri masih cenderung disempitkan artinya, terbatas pada bentuk kontak seksual dengan menafikan bentuk pelecehan nonkontak seksual, seperti exhibitionism dan pornografi. Ada tidaknya unsur paksaan sebenarnya tidak signifikan dalam kasus kejahatan seksual terhadap anak karena adanya kesenjangan pemahaman tentang seks antara orang dewasa dan anak-anak.

Sebagai orang tua kandung, pelaku seharusnya memberikan perlindungan kepada anaknya. Akibat dari pemerkosaan yang dilakukan orang tuanya sendiri korban akan mengalami bermacammacam masalah diantaranya : Trauma yang berkepanjangan yang mengakibatkan korban enggan bergaul dimasyarakat, Akibat menanggung aib, korban akan menjadi pemurung bahkan bisa-bisa mengakhiri hidupnya sendiri akibat menanggung malu.

Berdasarkan latar belakang permasalahan yang diadili oleh Majelis Hakim pada Pengadilan Negeri Menggala Register Perkara Nomor : 152/Pid.B/2010/PN.Mgl, maka permasalahan dalam penulisan ini adalah : Apa yang dimaksud dengan tindak pidana pemerkosaan? dan Apa dasar pertimbangan hukum Hakim atas Tindak Pidana Perkosaan yang dilakukan terhadap anak kandungnya?

\section{PEMBAHASAN}

\subsection{Tindak Pidana Pemerkosaan}

Pengertian tentang tindak pidana dalam Kitab Undang-undang 
Hukum Pidana (KUHP) dikenal dengan istilah stratbaar feit dan dalam kepustakaan tentang hukum pidana sering mempergunakan istilah delik, sedangkan pembuat undangundang merumuskan suatu undangundang mempergunakan istilah peristiwa pidana atau perbuatan pidana atau tindak pidana. Tindak pidana merupakan suatu istilah yang mengandung suatu pengertian dasar dalam ilmu hukum, sebagai istilah yang dibentuk dengan kesadaran dalam memberikan cirri tertentu pada peristiwa hukum pidana. Tindak pidana mempunyai pengertian yang abstrak dari peristiwa-peristiwa yang kongkrit dalam lapangan hukum pidana, sehingga tindak pidana haruslah diberikan arti yang bersifat ilmiah dan ditentukan dengan jelas untuk dapat memisahkan dengan istilah yang dipakai sehari-hari dalam kehidupan masyarakat.

Seperti yang diungkapkan oleh seorang ahli hukum pidana yaitu Prof. Moeljatno, SH, yang berpendapat bahwa pengertian tindak pidana yang menurut istilah beliau yakni perbuatan pidana adalah:

"Perbuatan yang dilarang oleh suatu aturan hukum larangan mana disertai ancaman (sanksi) yang berupa pidana tertentu, bagi barang siapa melanggar larangan tersebut."

Jadi berdasarkan pendapat tersebut di atas pengertian dari tindak pidana yang dimaksud adalah bahwa perbuatan pidana atau tindak pidana senantiasa merupakan suatu perbuatan yang tidak sesuai atau melanggar suatu aturan hukum atau perbuatan yang dilarang oleh aturan hukum yang disertai dengan sanksi pidana yang mana aturan tersebut ditujukan kepada perbuatan sedangkan ancamannya atau sanksi pidananya ditujukan kepada orang yang melakukan atau orang yang menimbulkan kejadian tersebut.

Dalam hal ini maka terhadap setiap orang yang melanggar aturanaturan hukum yang berlaku, dengan demikian dapat dikatakan terhadap orang tersebut sebagai pelaku perbuatan pidana atau pelaku tindak pidana. Akan tetapi haruslah diingat bahwa aturan larangan dan ancaman mempunyai hubungan yang erat, oleh karenanya antara kejadian dengan orang yang menimbulkan kejadian juga mempunyai hubungan yang erat pula.

Sehubungan dengan hal pengertian tindak pidana tersebut Bambang Poernomo, berpendapat bahwa perumusan mengenai perbuatan pidana akan lebih lengkap apabila tersusun sebagai berikut:

"Bahwa perbuatan pidana adalah suatu perbuatan yang oleh suatu aturan hukum pidana dilarang dan diancam dengan pidana bagi barang siapa yang melanggar larangan tersebut."

Adapun perumusan tersebut yang mengandung kalimat "Aturan hukum pidana" dimaksudkan akan memenuhi keadaan hukum di Indonesia yang masih mengenal kehidupan hukum yang tertulis maupun hukum yang tidak tertulis, Bambang Poernomo berpendapat mengenai kesimpulan dari perbuatan pidana yang dinyatakan hanya menunjukan sifat perbuatan terlarang dengan diancam pidana.

Maksud dan tujuan diadakannya istilah tindak pidana, perbuatan pidana, maupun peristiwa hukum dan sebagainya itu adalah untuk mengalihkan bahasa dari istilah asing stafbaar feit namun belum jelas apakah disamping 
mengalihkan bahasa dari istilah sratfbaar feit dimaksudkan untuk mengalihkan makna dan pengertiannya, juga oleh karena sebagian besar kalangan ahli hukum belum jelas dan terperinci menerangkan pengertian istilah, ataukah sekedar mengalihkan bahasanya, hal ini yang merupakan pokok perbedaan pandangan, selain itu juga ditengan-tengan masyarakat juga dikenal istilah kejahatan yang menunjukan pengertian perbuatan melanggar morma dengan mendapat reaksi masyarakat melalui putusan hakim agar dijatuhi pidana.

Tindak pidana adalah merupakan suatu dasar yang pokok dalam menjatuhi pidana pada orang yang telah melakukan perbuatan pidana atas dasar pertanggung jawaban seseorang atas perbuatan yang telah dilakukannya, tapi sebelum itu mengenai dilarang dan diancamnya suatu perbuatan yaitu mengenai perbuatan pidanya sendiri, yaitu berdasarkan azas legalitas (Principle of legality) asas yang menentukan bahwa tidak ada perbuatan yang dilarang dan diancam dengan pidana jika tidak ditentukan terlebih dahulu dalam perundangundangan, biasanya ini lebih dikenal dalam bahasa latin sebagai Nullum delictum nulla poena sine praevia lege (tidak ada delik, tidak ada pidana tanpa peraturan lebih dahulu), ucapan ini berasal dari von feurbach, sarjana hukum pidana Jerman. Asas legalitas ini dimaksud mengandung tiga pengertian yaitu:

a. Tidak ada perbuatan yang dilarang dan diancam dengan pidana kalau hal itu terlebih dahulu belum dinyatakan dalam suatu aturan undang-undang. b. Untuk menentukan adanya perbuatan pidana tidak boleh digunakan analogi.

c. Aturan-aturan hukum pidana tidak boleh berlaku surut.

Tindak pidana merupakan bagian dasar dari pada suatu kesalahan yang dilakukan terhadap seseorang dalam melakukan suatu kejahatan. Jadi untuk adanya kesalahan hubungan antara keadaan dengan perbuatannya yang menimbulkan celaan harus berupa kesengajaan atau kelapaan. Dikatakan bahwa kesengajaan (dolus) dan kealpaan (culpa) adalah bentuk-bentuk kesalahan sedangkan istilah dari pengertian kesalahan (schuld) yang dapat menyebabkan terjadinya suatu tindak pidana adalah karena seseorang tersebut telah melakukan suatu perbuatan yang bersifat melawan hukum sehingga atas`perbuatannya tersebut maka dia harus bertanggung jawabkan segala bentuk tindak pidana yang telah dilakukannya untuk dapat diadili dan bilamana telah terbukti benar bahwa telah terjadinya suatu tindak pidana yang telah dilakukan oleh seseorang maka dengan begitu dapat dijatuhi hukuman pidana sesuai dengan pasal yang mengaturnya.

Adapun maksud dari tindak Pidana pemerkosaan sebagaimana telah diatur dalam Kitab Undangundang Hukum Pidana ( KUHP ) Bab XIV tentang Kejahatan Kesusilaan yaitu Pasal 285 KUHP, yang berbunyi :

"Barang siapa dengan kekerasan atau ancaman kekerasan memaksa seorang wanita bersetubuh dengan dia, diluar pernikahan, untuk diancam karena melakukan perkosaan, dengan pidana 
penjara paling lama dua belas tahun."

Perumusan dalam KUHP tersebut, menetapkan beberapa kriteria untuk dapat mengkategorikan suatu perbuatan sebagai perkosaan, yakni :

1. Dengan kekerasan atau ancaman kekerasan; Bukan hanya kekerasan yang dipakai sebagai sarana, tapi bahkan ancaman untuk melakukan kekerasan sudah cukup.

2. Memaksa perempuan; Dalam hal ini berarti tidak ada persetujuan atau consent dari si perempuan.

3. Yang bukan istrinya; Apabila perempuan yang dipaksa adalah istri pelaku sendiri, maka hal ini tidak termasuk dalam perkosaan, walaupun ada kekerasan atau ancaman kekerasan Untuk bersetubuh ( Harkrisnowo, 1999 : 4-5).

Unsur- unsur perumusan tersebut berlaku secara kumulatif artinya disebut tindak pidana perkosaan apabila memenuhi unsurunsur tersebut.

Tindak perkosaan kebanyakan dilakukan oleh orang yang sudah dikenal korban dan biasanya terjadi dengan perencanaan yang baik dan pengamatan kegiatan korban seharihari oleh pelaku. Biasanya, pelaku melakukan perkosaan dengan penipuan, ancaman, kekerasan hingga korban tidak berdaya untuk melakukan perlawanan. ( Laila, 1999 : 87).

Tindak pidana perkosaan kebanyakan tidak ada saksi lain, selain korban. Hal inilah yang menyulitkan dalam pembuktiannya. Oleh karena itu, dibutuhkan adanya visum et repertum. Visum et repertum inilah yang nantinya dibawa dan dihadirkan ke persidangan oleh Jaksa Penuntut Umum sebagai alat bukti yang sah.

Untuk mengetahui perbuatan pidana perkosaan yang dilakukan terdakwa dalam perkara Nomor : 152/Pid B/2010/PM.Mgl, penulis melakukan analis terhadap perkara tersebut terhadap Terdakwa Yantasori Bin Nengkuasa Als Koneng

Terdakwa dalam perkara ini didakwa oleh Jaksa penuntut umum secara Komulatif yaitu : Dakwaan pertama didakwa melanggar ketentuan Pasal 81 Ayat (1) UU RI No. 23 Tahun 2002 Tentang Perlindungan anak Jo Pasal 64 ayat (1) KUHP tentang : Perbuatan berlanjut, dan dakwaan kedua didakwa melanggar Pasal 46 UU RI No.23 Tahun 2004 tentang Penghapusan Kekerasan Dalam Rumah Tangga Jo Pasal 64 ayat (1) KUHP tentang : Perbuatan berlanjut .

Adapun perbuatan pidana yang telah dilakukan terdakwa dalam dakwaan kesatu adalah sebagai berikut :

Bahwa pada hari, tanggal dan waktu yang sudah tidak dipastikan pada tahun 2006, sekitar jam 24.00 Wib, di gudang rumah tinggal Pelaku yang terletak di Blok III kampun Bumi Dipasena Utama kecamatan Rawajitu Timur kabupaten Tulang Bawang, Pelaku tidur bersama dengan keluarganya yaitu isteri pelaku dan kedua anak pelaku yaitu saksi korban dan saksi Syamsul Hadi bin Yantori serta ibu pelaku dalam satu kamar tidur, pada saat saksi korban dalam keadaan tidur, pelaku melepaskan sarung yang dikenakannya, kemudian pelaku berusaha memasukkan penisnya kedalam vagina korban, korban merasa vaginanya kesakitan dan mengeluarkan darah, perut saksi 
korban terasa sakit, terdakwa sambil memukul pundak saksi korban dan mengancam berkata "diam" sehingga korban terdiam ketakutan.

Keesokan harinya pada pukul $12.00 \mathrm{Wib}$, pada tempat yang sama pelaku bersama isterinya yaitu saksi Dalem Ratu Hindia Binti Cikdin serta saksi korban dan saksi Syamsul Hadi Bin Yantori sedang berada dirumahnya yang terle tak di Blok III Kampung Bumi Depasena Kec Rawajitu Timur Kabupaten Tulang Bawang, kemudian pelaku menyuruh isterinya Dalem Ratu Hindia serta Syamsul Hadi Bin Yantori untuk pergi kepasar. Setelah isterinya serta Syamsul Hadi Bin Yantori pergi kepasar, saksi korban duduk dikursi dalam rumahnya, sedangkan pelaku sedang mengasah pisau, tiba-tiba pelaku mendekati saksi korban dan berkata : "jangan bilang-bilang Ibu, nanti saya bunuh.

Bahwa pelaku telah melakukan perbuatan yang sama dengan memaksa saksi korban beberapa kali melakukan persetubuhan dengan cara pelaku yang memasukkan penisnya kedalam vagina saksi korban terjadi dibeberapa tempat keluarga mereka tinggal di kampong Bumi Depasena Utama sebanyak 4 (empat) kali, di kontrakkan jalan Anggrek sebanyak 2 (dua) kali dan dikontrakan jalan pisang sebanyan 2 (dua) kali dan setiap melakukan persetubuhan, pelaku selalu mengancam akan membunuh saksi korban jika melaporkan perbuatan pelaku kepada orang lain.

Bahwa akibat persetubuhan yang dilakukan pelaku, Perut saksi korban Nopitasari Binti Yantori semakin lama semakin membesar.
Pada hari Kamis tanggal 18 Februari 2010 sekitar pukul 9.00 Wib, bertempat dirumah kontrakan terdakwa di jalan pisang kampun Gedung Karya Jitu Kecamatan Rawa Jitu Selatan kabupaten Tulang Bawang, Ibu saksi Korban Yaitu Dalem Ratu Hindia Binti Cikdin, bertanya kepada saksi korban "Nopi perut kamu kok Gede? “ kemudian saksi korban menceritakan kepada saksi Dalem Ratu Hindia Binti Cikdin bahwa saksi korban beberapa kali disetubuhi oleh pelaku hingga hamil, namun saksi korban tidak berani menceritakan perbuatan pelaku, karena takut akan dibunuh pelaku.

Kemudian perbuatan pelaku dilaporkan kepada pihak yang berwajib untuk mempertanggungjawabkan.

Bahwa akibat perbuatan pelaku, saksi korban Nopitasari Binti Yantori mengalami kehamilan, berdasarkan Visum et Revertum Nomor 010/PKM-RJ/BP-I/V/2010 tanggal 18 Mei 2010 yang dibuat dan ditandatangani oleh Dr. Yuliana Indiani.

Perbuatan pelaku Yantori Bin Nengkuasa tersebut sebagai -mana diatur dan diancam pidana dalam pasal 81 ayat 1 UU RI No.23 Tahun 2002 Tentang Perlindungan anak Jo Pasal 64 ayat (1) KUHP.

\subsection{Pertimbangan hukum Hakim atas Tindak Pidana Perkosaan yang dilakukan terhadap anak kandung}

Berdasarkan hasil studi dokumen atas perkara Nomor : 152/Pid.B/2010/PN.Mgl an: Terdakwa Yantori Bin Nengkuasa Setelah Hakim mendengarkan keterangan saksi Korban, saksi 
Pelapor dan saksi-saksi lain, serta keterangan Terdakwa dan Bukti Visum Et Revertum dari Dokter, dan mendengar Tuntutan dari Jaksa Penuntut Umum Tanggal 26 Juli 2010 yang pada intinya memohon agar Majelis Hakim Menjatuhkan Hukuman Kepada Terdakwa selama 12 Tahun Penjara ,serta Pembelaan dari Terdakwa yang memohon keringanan hukuman, Maka Pada Tanggal 26 Juli tahun 2010,maka Hakim Menjatuhkan putusan.

Sebelum menjatuhkan putusannya ada beberapa pertimbangan hukum dari Majelis Hakim yaitu :

1. Menimbang bahwa oleh karena unsur-unsur dalam pasal $46 \mathrm{UU}$ RI No 23 tahun 2004 Tentang Penghapusan Kekerasan Dalam Rumah Tangga Jo Pasal 8 huruf a UU RI No 23 tahun 2004, Penghapusan Kekerasan Dalam Rumah Tangga Jo Pasal 64 ayat (1) KUHP telah terpenuhi dan perbuatan terdakwa dapat dipertanggung jawabkan, hakim berpendapat bahwa perbuatan terdakwa terbukti secara sah dan meyakinkan bersalah melakukan tindak pidana dan karenanya harus dipidana sebagaimana diatur dan diancam dalam pasal tersebut;

2. Menimbang bahwa sepenjang pemeriksaan perkara ini, pengadilan tidak menemukan alasan pembenar maupun pemaaf diri terdakwa yang dapat menghapuskan sifat melawan hukumnya perbuatan dan menghapuskan kesalahan terdakwa, maka oleh karena itu terdakwa harus dijatuhi pidana setimpal dengan kesalahannya;

3. Hal-hal yang memberatkan dari terdakwa Yantori Bin Nengkuasa telah menghancurkan masa depan saksi korban sebagai anak kandungnya sendiri;

4. Hakim dalam pertimbangannya tidak menemukan alasan sebagai hal-hal yang meringankan bagi diri pelaku.

Kemudian, Majelis Hakim telah menjatuhkan Putusan atas perbuatan pelaku dengan amar putusan ; Menyatakan bahwa pelaku telah terbukti secara sah dan meyakinkan bersalah melakukan tindak pidana " Melakukan persetubhan terhadap anak dengan kekerasan secara berlanjut", dan Menjatuhkan pidana terhadap Pelaku oleh karena itu dengan pidana penjara selama 12 (dua belas) tahun.

Berdasarkan atas pertimbangan hukum dan atas putusan yang dijatuhkan oleh Majelis Hakim dalam perkara Nomor 52/Pid.B/2010/PN.Mgl atas pelaku tersebut, maka menurut analisa penulis bahwa didalam Dakwaan Jaksa Penuntut Umum yakni pada dakwaan ke satu melanggar ketentuan pasal 81 Aat (1) UU RI No. 23 Tahun 2002 Tentang Perlindungan anak yang menyebutkan setiap orang yang dengan sengaja melakukan kekerasan atau ancaman kekerasan memaksa anak melakukan persetubuhan dengannya atau dengan orang lain, dipidana dengan pidana penjara paling lama 15 (lima belas) tahun dan paling singkat 3 (tiga) tahun dan denda paling banyak Rp300.000.000,00 (tiga ratus juta rupiah) dan paling sedikit Rp $60.000 .000,00$ (enam puluh juta rupiah).

Pertimbangan Hakim tersebut antara lain menyebutkan, bahwa unsur-unsur dalam pasal 46 UU RI 
No. 23 tahun 2004 Tentang Penghapusan Kekerasan Dalam Rumah Tangga Jo Pasal 8 huruf a UU RI No 23 tahun 2004, Penghapusan Kekerasan Dalam Rumah Tangga Jo Pasal 64 ayat (1) KUHP telah terpenuhi dan perbuatan terdakwa dapat dipertanggung jawabkan, hakim berpendapat bahwa perbuatan terdakwa terbukti secara sah dan meyakinkan bersalah melakukan tindak pidana, dan pengadilan tidak menemukan alasan pembenar maupun pemaaf diri terdakwa yang dapat menghapuskan sifat melawan hukumnya perbuatan dan menghapuskan kesalahan terdakwa serta, hal-hal yang memberatkan dari terdakwa adalah telah menghancurkan masa depan saksi korban sebagai anak kandungnya sendiri dan Hakim dalam pertimbangannya tidak menemukan alasan sebagai hal-hal yang meringankan bagi diri pelaku, dan kemudian hakim penjatuhkan putusan pidana, selama 12 tahun penjara.

Menurut penulis, dari pertimbangan hakim tersebut kemudian, sudah tepat pertimbangan hakim yang menyatakan bahwa unsur-unsur dalam pasal 46 UU RI No 23 tahun 2004 Tentang Penghapusan Kekerasan Dalam Rumah Tangga Jo Pasal 8 huruf a UU RI No 23 tahun 2004, Penghapusan Kekerasan Dalam Rumah Tangga Jo Pasal 64 ayat (1) KUHP telah terpenuhi dan perbuatan terdakwa dapat dipertanggung jawabkan, Hakim yang hanya menjatuhkan hukuman selama 12 Tahun kepada terdakwa adalah kurang maksimal/kurang berat, karena tidak sesuai dengan pertimbangan dari hakim, yang menyatakan bahwa terhadap diri terdakwa tidak ada hal-hal yang meringankan, oleh kerena tidak ada hal-hal yang meringankan atas diri terdakwa maka menurut hemat penulis, hukuman yang dijatuhkan oleh Majelis Hakim adalah hakim harus menjatuhkan hukuman dengan ancaman hukuman terberat yaitu selama 15 tahun, sebagaimana yang diancamkan dalam surat dakwaan yang dinyatakan terbukti, dalam hal ini dinyatakan terbukti melanggar ketentuan pasal 81 ayat 1 UU RI No.23 Tahun 2002, adalah selama 15 (lima belas) tahun, bukan selama 12 tahun, kecuali apabila dalam pertimbangan hakim, ada hal-hal yang meringankan bagi diri terdakwa.

Hukuman yang dijatuhkan oleh Hakim dalam perkara tersebut adalah kurang cermat, karena seharusnya, selain Hakim menjatuhkan hukuman Penjara, juga harus menjatuhkan hukuman denda paling sedikit $\mathrm{Rp}$ $60.000 .000,00$ (enam puluh juta rupiah). Karena dalam ketentuan pasal 81 ayat 1 UU RI No.23 Tahun 2002 disebutkan Setiap orang yang dengan sengaja melakukan kekerasan atau ancaman kekerasan memaksa anak melakukan persetubuhan dengannya atau dengan orang lain, dipidana dengan pidana penjara paling lama 15 (lima belas) tahun dan paling singkat 3 (tiga) tahun dan denda paling banyak Rp300.000.000,00 (tiga ratus juta rupiah) dan paling sedikit Rp 60.000.000,00 (enam puluh juta rupiah).

\section{PENUTUP}

\subsection{Simpulan}

1. Perkosaan adalah apabila dengan kekerasan atau ancaman kekerasan, memaksa perempuan 
yang bukan istrinya untuk melakukan persetubuhan.

2. Pertimbangan hakim dalam perkara Nomor 152/Pid.B/2010/ PN.Mgl, antara lain :

a. Hakim berpendapat bahwa perbuatan Pelaku terbukti secara sah dan meyakinkan bersalah melakukan tindak pidana dan karenanya harus dipidana sebagaimana diatur dan diancam dalam pasal 8huruf a , UU RI No.23 Thn 2004 Tentang Kekerasan Dalam Rumah Tangga Jo Jo Pasal 64 (1) KUHP;

b. Pertimbangan lainnya pengadilan tidak menemukan alasan pembenar maupun pemaaf diri pelaku yang dapat menghapuskan sifat melawan hukumnya perbuatan dan menghapuskan kesalahan terdakwa;

c. Adapun Hal-hal yang memberatkan dari pelaku, karena telah menghancurkan masa depan saksi korban sebagai anak kandungnya sendiri, sedangkan hakim dalam pertimbangannya tidak menemukan alasan sebagai hal-hal yang meringankan pelaku.

\subsection{Saran}

1. Tidak ditemukan dasar yang meringankan terdakwa, seharusnya hukuman yang dijatuhkan kepada Pelaku Tindak pidana pemerkosaan terhadap anak kandung dalam perkara ini adalah 15 tahun, ditambah dengan hukuman denda, paling sedikit Rp 60.000.000,- (Enam Puluh Juta Rupiah).
2. Pemerintah dan seluruh masyarakat harus berpartisipasi untuk mencegah terjadinya kekerasan seksual dalam rumah tangga, dan orang tua harus lebih mengawasi anak-anak dengan siapa mereka berhubungan sehingga dapat di cegah terjadi korban-korban kekerasan seksual yang baru.

\section{DAFTAR PUSTAKA}

Soeidy Sholeh, Dasar Hukum Perlindungan Anak, Penerbit CV. Navindo Pustaka Mandiri, Jakarta, 2001.

Moeljatno, Asas-asas Hukum Pidana, Jakarta: Bina Aksara, 1987.

Poernomo Bambang, Asas-asas Hukum Pidana, Jakarta : Ghalia Indonesia. 1992

P.A.F. Lamintang, Dasar-dasar Hukum Pidana Indonesia; Bandung PT. Citra Aditya Bakti, 1997.

Kitab Undang-Undang Hukum Acara Pidana (KUHAP), Karya Anda, Surabaya.

M. Faal, Penyaringan Perkara Pidana oleh Polisi (Diskresi Kepolisian), PT. Pradnya Paramita, Jakarta, 1991.

R. Soesilo, Taktik dan Teknik Penyidikan Perkara Kriminal, Politeia, Bogor, 1989.

Soerjono Soekanto, 1984, Pengantar Penelitian Hukum, UI Press Jakarta.

Andi Hamzah, Asas-asas Hukum Pidana ; Jakarta, PT Rineka Cipta,Tahun 2004.

Adami Chazawi, Pelajaran Hukum Pidana Bagian I; Jakarta, PT. Raja Grafindo Persada, Tahun 2007. 
Muhrisun Afandi, artikel : Pedofilia,

Belajar dari Kasus Mantan

Diplomat.

Darwan Printis, Hukum Anak

Indonesia, Bandung

PT.Citra Aditya Bakti,1997.

H.R. Abudsalam, Hukum

Perlindungan Anak, Jakarta

Restu Agung Tahun 2007.

Undang-Undang No 4 Tahun 1979,

Tentang Kesejahteraan

Anak.

Undang-Undang No.3 Tahun 1997

Tentang Pengadilan Anak

Undang-undang N0 23 Tahun 2002, Tentang Perlindungan

Anak.

Kitab Undang-Undang Hukum

Pidana 